\title{
Spent Brewer's Yeast Autolysates as a New and Valuable Component of Functional Food and Dietary Supplements
}

Podpora B, Świderski F, Sadowska A*, Piotrowska A and Rakowska R

Department of Functional and Organic Food and Commodities, Faculty of Human Nutrition and Consumer Sciences, Warsaw University of Life Sciences, Warsaw, Poland

\begin{abstract}
The aim of the work was to obtain autolysates derived from spent brewer's yeast and demonstrate their potential capabilities as a natural and valuable ingredients intended for functional food and dietary supplements production. The research material consisted of yeast Saccharomyces cerevisiae which was the remains after the beer production process. In these autolysates the following analyses were performed - protein, dry matter and amino acids content, determination of molecular weight of proteins, antioxidant properties and sensory quality. It was found that the tested autolysates were characterised by a high content of essential amino acids, exciding the amount present in the reference protein developed by FAO/WHO. The sensory quality of the tested autolysates was dependent on the degree of autolysis process of the yeast protein which further determined their usage in a food production. Precise time control of the autolysis process allows obtaining a product with the designed functional properties, characterised by the desired content of free amino acids, peptides with a specific molecular weight and high antioxidant properties. Based on the obtained results it can be concluded that the post-fermentation yeast may be a valuable raw material for the preparation of yeast autolysates which may be new and valuable component in functional food and dietary supplements production.
\end{abstract}

Keywords: Spent brewer's yeast; Yeast's autolysates; Functional food; Supplements

\section{Introduction}

Brewer's yeast is increasingly finding application in the food industry, due to its high functional properties. Most post-fermentation brewer's yeast, which is a waste product, was used as a source of $\mathrm{B}$ vitamins, protein and minerals in animal feed production [1]. Nowadays, more and more companies are involved in the processing of post-fermentation yeast products with bioactive properties to be used in the production of functional food. Some bioactive compounds, such as $\beta$-glucans, monooligosaccharides, significant amounts of $B$ vitamins, minerals and also yeast extracts can be obtained from the post-fermentation yeast. Yeast extracts are more widely used as a natural flavouring preparation of meat profile which replaces protein hydrolysates obtained by acid hydrolysis. Yeast extracts are produced by breaking the cell walls with the use of endogenous or exogenous enzymes [2-4]. The methods of the manufacturing preparation of extracts are divided into hydrolysis and autolysis. Hydrolysis is the most efficient method of yeast solubilisation. Yeast extracts prepared by the use of acids or the addition of enzymes is known as 'yeast hydrolysates'. Despite a high production yield, acid hydrolysis is less attractive to the manufacturers because of relatively high salt content and high probability of carcinogenic compounds content, such as monochloropropanol and dichloropropanol [5]. Autolysis with using the endogenous enzymes occurs in yeast when the cell growth cycle is completed and the death phase is initiated $[3,6]$. Intracellular enzymes are activated by appropriate process conditions, such as temperature and time, which results in a partial degradation of the cell wall structures. This allows extracting valuable proteins, carbohydrates and vitamins from the cells, preserving their native structure. Autolysates are the purest product group, as hydrolysates contain large amounts of salt or sodium used during plasmolysis process or to neutralise the acids used in the hydrolysis process, respectively $[7,8]$. Currently, yeast autolysates are used in the fermentation industry, especially as starting materials and in the food industry mainly as flavour enhancers [9-11].

In the literature, there are only few reports on the possibility of the application of the post-fermentation yeast for the production of yeast extracts, which are characterised by the preferred nutritional properties, that may be used in functional food and dietary supplements production. The aim of this study was to investigate the possibility of using post-fermentation yeast in order to obtain yeast autolysates with the properties valuable from a nutritional point of view that can be used as a natural ingredient in functional food and dietary supplements production

\section{Material and Methods}

\section{Material}

Material consisted of yeast autolysates obtained from the fermented yeast slurry of Saccharomyces cerevisiae, which is a byproduct of the brewing industry. The slurry was subjected to a filtration process (to remove physical impurities) and centrifugation (to remove beer residual). The feedstock was then subjected to a standardisation process to obtain the following parameters: dry matter content: $15,5-16,5 \%$, protein content: $\min .42 \%, \mathrm{pH}(5,2-6,2)$, suitable flocculation and content of viable yeast cells. Selected yeast slurry in an amount of 3000 $\mathrm{g}$ was transferred to the autolytic reactor placed in an oil bath filled with polyethylene glycol. The slurry was subjected to pre-incubation at $38^{\circ} \mathrm{C}$ for 4 hours to completely fermentate sugars remaining in the yeast slurry. Autolysis was carried out at $47^{\circ} \mathrm{C}$ during $48 \mathrm{~h}$. After starting the reactor, the stirrer was working during the whole process. During the

*Corresonding author: Anna Sadowska, Department of Functional and Organic Food and Commodities, Faculty of Human Nutrition and Consumer Sciences, Warsaw University of Life Sciences, Nowoursynowska, Warsaw, Poland, Tel: 4822-5931000; Email: anna sadowska@sggw.pl

Received October 06, 2015; Accepted November 03, 2015; Published Novembe 16, 2015

Citation: Podpora B, Świderski F, Sadowska A, Piotrowska A, Rakowska R (2015) Spent Brewer's Yeast Autolysates as a New and Valuable Component of Functional Food and Dietary Supplements. J Food Process Technol 6: 526. doi:10.4172/2157-7110.1000526

Copyright: $\odot 2015$ Podpora B, et al. This is an open-access article distributed under the terms of the Creative Commons Attribution License, which permits unrestricted use, distribution, and reproduction in any medium, provided the original author and source are credited. 
trial the samples were taken for testing at specified intervals. In order to inactivate the lytic enzymes obtained samples were heated at $95^{\circ} \mathrm{C}$ for $30 \mathrm{~min}$. Tested yeast autolysates were in liquid form, they were not subjected to compaction nor drying process. The protein and dry matter content in autolysates used for the study was respectively $7.53 \pm$ $0.34 \%$ and $14.45 \pm 0.03 \%$

\section{Methods}

Chemical composition of autolysates was conducted referring to the method of AOAC [12]. In the autolysates the dry matter content was determined using the gravimetric method. The content of the nitrogen was analysed by the Kjeldahl method using a conversion factor of 6.25 for nitrogen quantities of protein content.

Determination of amino acids content in tested extracts was followed by acid hydrolysis in order to carry out the peptide bonds hydrolysis until they reach the free amino acids. After hydrolysis the derivatization using dansyl chloride was done, and then amino acids were separated and determined using high performance liquid chromatography UV/VIS [13]. For determination of tryptophan alkaline hydrolysis was used. The tryptophan was determined by using HPLC with fluorescence detection [14]. On the basis of the amino acid composition Chemical Score (CS) [15] and Essential Amino Acid Index (EAAI) were calculated [16]. As the pattern of the protein amino acid composition the standards of whole egg and these developed by FAO/WHO [17] were adopted.

Determination of molecular weights of proteins by mass spectrometry was performed using a mass spectrometer equipped with a MALDI ion source type. For the analysis, the mass spectrometer MALDI-TOF Reflex IV (Bruker-Daltonics, Bremen, Germany) was used. The analysis was performed at a linear mode operation mass spectrometer in the range $500-5500 \mathrm{~m} / \mathrm{z}, 2000-19000 \mathrm{~m} / \mathrm{z} 10000$ $105000 \mathrm{~m} / \mathrm{z}$. As a matrix the sinapic acid (SA) and the a-cyano4-hydroxycinnamic acid (HCCA) (dissolved in a solution of 2:1 acetonitrile in water to saturate the solution) were used. Each sample was thoroughly mixed and centrifuged $\left(10000 \mathrm{RCF}, 10 \mathrm{~min}, 4^{\circ} \mathrm{C}\right)$. Then, the supernatant was diluted five times with $0.1 \%$ TFA. On the plate $0.5 \mathrm{ml}$ of the prepared sample with $0.5 \mathrm{~mL}$ of the matrix was loaded and then the plate was allowed to dry. After drying, the sample was introduced into the mass spectrometer ion source and ionized. There was $1 \mu \mathrm{g}$ of sample used for a single analysis. The nominal sensitivity of the spectrometer for the peptides of $1000-5000 \mathrm{~m} / \mathrm{z}$ was $1 \mathrm{fmol}$.

Determination of peptides with a specific molecular weight range using LC-MS was performed using high performance liquid chromatography coupled with a mass detector LTQ Thermo Finnigan. Each sample was thoroughly mixed, collected in tubes of Falcone type in an amount of $10 \mathrm{ml}$ and then centrifuged ( $15 \mathrm{~min}, 4000 \mathrm{RCF}$, $4^{\circ} \mathrm{C}$ ). To clean tubes $5 \mathrm{ml}$ of the supernatant was collected and was acidified with $10 \%$ TFA to $\mathrm{pH}<3$. Thus prepared samples were loaded on a C18 SPE column (200 mg, Merck), after activation the bed ( $3 \mathrm{~mL}$ $0.1 \%$ TFA in $80 \%$ acetonitrile, $3 \mathrm{ml} 0.1 \%$ TFA). Then the column was washed with $3 \mathrm{~mL}$ of $0.1 \%$ TFA, dried and eluted with $3 \mathrm{ml}$ of $0.1 \%$ TFA in $40 \%$ acetonitrile. The eluent was freeze-dried for over $12 \mathrm{~h}$, the dry residue was taken up in $100 \mu \mathrm{l}$ of $0.1 \%$ formic acid and injected on LC-MS. Spectra MS-MS was performed based on the calculation program OMSSA using the Swissprot database, for peptides derived from proteins of yeast (Saccharomyces cerevisiae) without the specified proteases.

The antioxidant properties were determined by spectrophotometric method, "in vitro", using the synthetic ABTS radicals according to Pellegrini et al. [18] method. The content of polyphenols was determined by the method of Singleton and Rossi [19], using the FolinCiocolteu reagent.

Detailed sensory characteristics of extracts samples was performed by a quantitative descriptive analysis (Quantitative Descriptive Analysis - QDA), using the analytical procedure described in BS EN ISO 13299:2010 [20] 24 quality parameters were selected to analyse the profile of the extracts. The sensory evaluation of the samples was conducted by 8-person team of evaluators who are qualified assessors - experts, with theoretical and practical preparation in the field of sensory methods. The sensory evaluation was performed in two independent replications. Ratings were performed at the Laboratory of Sensory Analysis, which meets all the requirements specified in BS EN ISO 8589:2010 standard [21]. For planning sessions with ratings scaling method, generation of random numbers for coding samples, records of individual results and their pre-treatment a computerised support system of sensory analysis ANALSENS NT was used.

Statistical analysis of the results was performed using STATISTICA 10 software. The significance of differences in chemical research of yeast aytolysates was verified using one-way analysis of variance (ANOVA). In order to study the differences between groups, a Duncan test ( $\alpha$ $=0.05)$ was used. The graphic projections of distribution of tested aytolysates in the coordinate system formed by two main factors were prepared in the ANALSENS based on the covariance matrices.

\section{Results and Discussion}

The sum of amino acid of yeast autolysates obtained by varying autolysis time is shown in Table 1. Along with prolonged autolysis time, there was an increase of free amino acids - it reached a level of $11.2 \%$ after $2 \mathrm{~h}$ and $77.5 \%$ after 48 hours. The obtained results of amino acid content of yeast autolysates obtained in the present work is different from the amino acid composition of pure brewer's yeast, Saccharomyces cerevisiae. Brewer's yeast contain substantially lower amount of glutamic acid, proline and arginine [22,23]. This is due to the fact that the autolysates investigated in the present work were not prepared from pure brewer's yeast but from their suspension in the wort remaining in the brewing process, which is rich in proteins, peptides and free amino acids derived from barley malt and other additives used in beer production. Consequently, the amino acid profile of the obtained autolysates is much more developed and is characterised by a much higher concentration of amino acids that are normally present in yeast cells in minor amounts. The amino acid profile in such case is dependent on the wort composition [24,25].

On the basis of the obtained data the amino acid content in autolysates was converted to gram of protein and the results were compared to a WHO/FAO [17] standard (Table 2). Among egzogenous amino acids there was a large number of phenylalanine, threonine, tryptophan and valine. These amino acids are not typical for the

\begin{tabular}{|l|c|c|c|c|c|c|c|c|}
\hline & \multicolumn{7}{|c|}{ AUTOLYSATES } \\
\cline { 2 - 9 } & $\mathbf{2 h}$ & $\mathbf{6 h}$ & $\mathbf{8 h}$ & $\mathbf{1 0 h}$ & $\mathbf{1 2 h}$ & $\mathbf{1 6 h}$ & $\mathbf{2 0 h}$ & $\mathbf{4 8 h}$ \\
\hline $\begin{array}{l}\text { Sum of the free amino } \\
\text { acids [g/100 g of dry } \\
\text { weight] }\end{array}$ & 4.69 & 8.44 & 9.29 & 9.77 & 10.17 & 12.45 & 16.06 & 32.38 \\
\hline $\begin{array}{l}\text { Percentage of free } \\
\text { amino acids } \\
\text { [\%] }\end{array}$ & 11.2 & 20.2 & 22.2 & 23.4 & 24.3 & 29.8 & 38.4 & 77.5 \\
\hline
\end{tabular}

Table 1: The amino acid composition of yeast autolysates after the autolysis process, per $\mathrm{g} / 100 \mathrm{~g}$ of dry weight. 


\begin{tabular}{|c|c|c|c|}
\hline \multirow[t]{2}{*}{ Amino Acids } & Autolysate & $\begin{array}{c}\text { Reference Protein } \\
\text { According To Fao/Who }\end{array}$ & $\left.\mathrm{CS}^{\star *}\right)$ \\
\hline & $\mathrm{mg} / \mathrm{g}$ of protein & $\mathrm{mg} / \mathrm{g}$ of protein & $\%$ \\
\hline Isoleucine (EG.)*) & 23.7 & 28 & 84.6 \\
\hline $\begin{array}{l}\text { Leucine }+ \text { Norleucine } \\
\text { (EG.) }\end{array}$ & 65.1 & 66 & 98.7 \\
\hline Lysine (EG.) & 47.2 & 58 & 81.4 \\
\hline $\begin{array}{l}\text { Methionine (EG.) + } \\
\text { Cysteine }\end{array}$ & 23.8 & 25 & 92.0 \\
\hline $\begin{array}{l}\text { Phenylalanine (EG.) + } \\
\text { Tyrosine }\end{array}$ & 90.6 & 63 & 143.8 \\
\hline Threonine (EG.) & 61.3 & 34 & 180.3 \\
\hline Tryptophan (EG.) & 11.9 & 11 & 108.2 \\
\hline Valine (EG.) & 69.7 & 35 & 199.2 \\
\hline $\begin{array}{l}\text { Sum of exogenous } \\
\text { amino acids }\end{array}$ & 393.3 & 320 & - \\
\hline $\mathrm{EAAI}^{* * *}$ ) & 117 & 100 & - \\
\hline
\end{tabular}

*) EG. - essential amino acids

$\left.{ }^{* *}\right)$ CS - chemical score

${ }^{\star * *}$ ) EAAI - essential amino acids index

Table 2: Comparison of the content of essential amino acids in the yeast's autolysate after $48 \mathrm{~h}$ of autolysis in relation to the content of amino acids in protein standard established by the FAO/WHO [17]

yeast amino acids but more particularly for plant proteins, especially for barley's proteins [26]. It was found that the limiting amino acids in the obtained autolysates was primarily lysine and in lesser extent isoleucine, where the rate of limiting amino acid content to a reference protein developed by FAO/WHO is $81.4 \%$ for lysine and $84.6 \%$ for isoleucine. The data indicate that the obtained autolysates are very valuable source of series of amino acids, such as tryptophan, valine, threonine and phenylalanine+tyrosine. The content of these amino acids, as compared to the reference protein developed by FAO/WHO, was significantly higher, ranging from $143.8 \%$ for valine + tyrosine to $199.2 \%$ for valine. It is worth emphasizing that the tested autolysates were characterised by a high sum of the exogenous amino acids of about $303.3 \mathrm{mg} / \mathrm{g}$ of protein. This value is much higher than the total amino acids present in the reference protein developed by FAO/WHO. The integrated ratio of essential amino acids (EAAI), as an indicator of the maximum potential nutritional value of the protein [27] reached $117 \%$ for the tested autolysates in relation to a reference protein by $\mathrm{FAO} / \mathrm{WHO}$. It can be concluded that the autolysates obtained from post-fermentation yeast are a valuable source of amino acids, which is important from a nutritional point of view. These amino acids come not only from yeast but also from the components used for the beer production (e.g., malt and hops). A high total content of amino acids in yeast autolysates, superior to that present in the reference protein developed by the $\mathrm{FAO} / \mathrm{WHO}$, indicates that these autolysates can be a valuable component of several products from the group of functional food and dietary supplements. The obtained autolysates are characterised by a different degree of hydrolysis, resulting in obtaining a product with a high and low content of free amino acids which allows expanding their use depending upon of the desired functional characteristics of the proposed application.

MALDI-TOF-MS analysis of yeast autolysates showed the presence of small amounts of the compounds with masses in the range of 1000$6000 \mathrm{Da}$. The peaks were characterised by a small intensity and mainly limited to the range of $1000-2500 \mathrm{~m} / \mathrm{z}$ (Figure 1). The most intense peak in all the investigated autolysates was found in the vicinity of $2414 \mathrm{~m} / \mathrm{z}$. In all the autolysates there were no peaks in the range of $10000-15000 \mathrm{~m} / \mathrm{z}$ or substances of high molecular weight (up to 200000 $\mathrm{m} / \mathrm{z}$ ). Given the fact that the average molecular weight of amino acid is approximately $110 \mathrm{Da}$, it can be assumed that the peptides formed in the process of autolysis contain 20-30 amino acid residues [28]. Literature data indicates that in the composition of the autolysates obtained on industrial scale free amino acids represent $35-45 \%$, di-, triand tetrapeptides of a molecular weight of less than $600 \mathrm{Da}$ constitutes $10-15 \%$, oligopeptides of 2000-3000 Da weight constitute $40-45 \%$, whereas those with a mass of 3000-100000 Da represent only 2-5\%. These values refer to the total protein present in autolysates $[3,11,29]$. Table 3 shows the results of the molecular masses of the peptides present in the obtained yeast autolysates, according to the duration of the autolysis process. The molecular masses were defined on the basis of the calculation resulting from the molecular ion $(\mathrm{m} / \mathrm{z})$, charge and the areas under the peak for the identified peptides. The presence of peptides with masses of 1000-2000 Da was revealed in the analysed autolysates. Based on these results it can be concluded that the amount of peptide in each sample decreases with lenghtening the autolysis duration, due to the fact that they are decomposed into free amino acids. There are known applications of protein hydrolysates with a high degree of hydrolysis, in which the majority are the peptides with a molecular weight less than $2500 \mathrm{Da}$ in the feeding of young children or people with allergies. In the literature there are studies showing that the loss of immunogenic properties is due to the loss of tertiary structure of proteins as a result of their hydrolysis. It was demonstrated that peptides of molecular weight less than $10 \mathrm{kDa}$ are the tolerance limits but they may have little allergenic properties.

Currently, products of different composition can be found on the market. In these products, depending on the application, differences in the content of peptides of certain molecular weights can be determined. In addition to molecular weight of peptides, an additional important

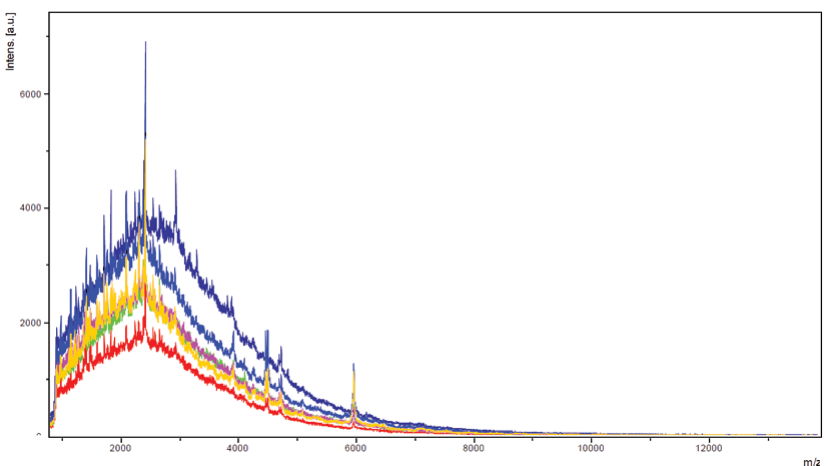

Figure 1: Comparison of the spectra obtained for the tested autolysate samples at different autolysis time $(6 \mathrm{H}, 8 \mathrm{H}, 10 \mathrm{H}, 12 \mathrm{H}, 16 \mathrm{H}, 20 \mathrm{H})$ in the range of $1000-15000 \mathrm{~m} / \mathrm{z}$.

\begin{tabular}{|c|c|c|c|c|}
\hline \multirow[t]{2}{*}{$\begin{array}{l}\text { Autolysis } \\
\text { Time }\end{array}$} & \multirow{2}{*}{$\begin{array}{l}\text { Number Of } \\
\text { Identified } \\
\text { Peptides }\end{array}$} & \multicolumn{3}{|c|}{$\begin{array}{c}\text { Percentage Of Identified Peptides In The Mass } \\
\text { Range }\end{array}$} \\
\hline & & $<1000 \mathrm{Da}$ & $1000-2000 \mathrm{Da}$ & $>2000 \mathrm{Da}$ \\
\hline $2 \mathrm{~h}$ & 64 & 0,27 & 96,10 & 3,63 \\
\hline $6 \mathrm{~h}$ & 43 & 8,18 & 87,20 & 4,62 \\
\hline $8 \mathrm{~h}$ & 34 & 3,72 & 89,94 & 6,34 \\
\hline $10 \mathrm{~h}$ & 37 & 4,01 & 95,20 & 0,79 \\
\hline $12 \mathrm{~h}$ & 37 & 0,73 & 94,62 & 4,65 \\
\hline $16 \mathrm{~h}$ & 35 & 1,04 & 89,08 & 9,88 \\
\hline $20 \mathrm{~h}$ & 29 & 1,10 & 86,25 & 12,65 \\
\hline $48 \mathrm{~h}$ & 22 & 2,52 & 74,28 & 23,20 \\
\hline
\end{tabular}

Table 3: The percentage of the peptides identified in the individual ranges of the masses. 
aspect is the source and the way of their reception as well as the ratio of branched chain amino acids to aromatic peptides [30-32]

The results of the antioxidant activity and the content of polyphenolic compounds found in the tested yeast autolysates are shown in Table 4 . The obtained results indicate that the test autolysates are characterised by a high antioxidant activity, ranging from 22.18 to $32.73 \mathrm{mMol}$ TEAC/100 ml. The content of polyphenolic compounds ranged from 228.3 to $336.1 \mathrm{mgGAE} / 100 \mathrm{ml}$. High antioxidant activity is likely to be related to the presence grade of polyphenolic compounds, which are derived from hops and malt used for beer production and the grade of proteins degradation to amino acids. Yeast autolysates may further contain Maillard reaction products and glutathione. It has been shown that the antioxidant activity of Maillard reaction products is dependent on the amino acid sequence of the dipeptides (the constituents of the yeast autolysates). Fresh baker's yeast contains about $0.65 \%$ of glutathione and after processing this content may increase up to $5 \%$. It has been shown that the addition of glutathione to butter in the amount of $0.01-0.02 \%$ significantly slowed down the process of rancidity $[11,33]$. Studies have shown that whey protein and soy hydrolysates have antioxidant properties. Short peptides are probably responsible for this action [34]. The strongest antioxidant properties have soy hydrolysates containing mainly peptides of a size 0.7-1.4 kDa [34]. During analysing of the obtained results it was noted that the antioxidant activity increased with the increase in duration of the autolysis process wherein the autolysates obtained after $16 \mathrm{~h}$ and $20 \mathrm{~h}$ of autolysis process did not differ statistically significantly both in terms of its antioxidant properties and the content of polyphenolic compounds. In the context of this study, the sensory evaluation of autolysates solutions was performed depending both on the duration of the autolysis process (compared to samples obtained after 6, 8, 10 and 20 hours of autolysis process) and autolysate concentration in the aqueous solution $(0.7 \%, 3.6 \%$, and $7 \%)$. Principal Components Analysis (Figure 2) showed that the autolysate solutions differed one from another considering their concentration (0.7, 3.6 and 7\%). The vast majority of variation $(87.38 \%)$ was assigned to the first component and set out the main changes in the sensory profile of the tested autolysates. Location of autolysate solutions next to each other proves their significant similarity. The first group consisted of samples representing the lowest concentration of autolysate, which showed a much lower intensity parameters in both a positive and negative, and overall quality. Location of autolysates of higher concentrations on the opposite side than the samples $(0.7 \%)$ after $6 \mathrm{~h}, 8 \mathrm{~h}, 10 \mathrm{~h}$ and $20 \mathrm{~h}$ of autolysis process confirmed their differences. The odour of the samples obtained in the various duration of the autolysis process and prepared in a concentration of $3.6 \%$ was primarily cereal, bouillon, yeast and acidic. In the samples representing the highest concentration of autolysate (7\%) such sensory trials as fermentation, beer, yeast and tart

\begin{tabular}{|c|c|c|c|c|}
\hline \multirow{2}{*}{$\begin{array}{l}\text { Autolysis } \\
\text { Time }\end{array}$} & \multicolumn{2}{|c|}{ Antioxidant activity Xav. (SD) } & \multicolumn{2}{|c|}{$\begin{array}{c}\text { Polyphenolic compounds } \\
\text { Xav. (SD) }\end{array}$} \\
\cline { 2 - 5 } & \multicolumn{2}{|c|}{ mMol TEAC/100 $\mathbf{~ l}$} & \multicolumn{2}{c|}{ mg GAE/100 ml } \\
\hline $\mathbf{6} \mathbf{~ h}$ & $22,18^{\mathrm{a}}$ & $(0,24)$ & $228,34^{\mathrm{a}}$ & $(1,59)$ \\
\hline $\mathbf{8} \mathbf{~ h}$ & $24,78^{\mathrm{b}}$ & $(0,26)$ & $274,82^{\mathrm{b}}$ & $(1,35)$ \\
\hline $\mathbf{1 0} \mathbf{~ h}$ & $27,36^{\mathrm{c}}$ & $(0,12)$ & $300,30^{\mathrm{c}}$ & $(2,10)$ \\
\hline $\mathbf{1 2} \mathbf{~ h}$ & $30,04^{\mathrm{d}}$ & $(0,33)$ & $307,02^{\mathrm{d}}$ & $(1,51)$ \\
\hline $\mathbf{1 6} \mathbf{~ h}$ & $32,73^{\mathrm{e}}$ & $(0,22)$ & $329,98^{\mathrm{e}}$ & $(1,28)$ \\
\hline $\mathbf{2 0} \mathbf{h}$ & $32,71^{\mathrm{e}}$ & $(0,19)$ & $336,14^{\mathrm{e}}$ & $(1,28)$ \\
\hline
\end{tabular}

Xav-the average content; SD-the standard deviation; ${ }^{\text {a-e }}$ the mean values in columns indicated with different letters differed significantly $(\alpha=0,05)$

Table 4: The antioxidant activity and the content of polyphenolic compounds of yeast autolysates obtained during the autolysis process.

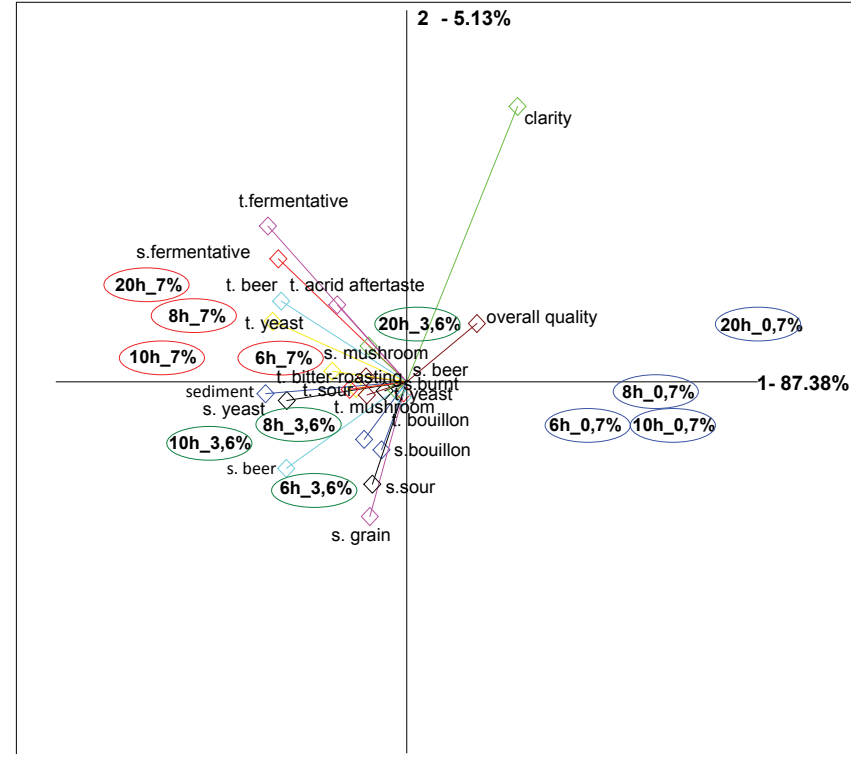

Figure 2: Similarities and differences in the sensory characteristics of the tested yeast autolysates.

predominated. Analysing the effect of concentration on the sensory quality of yeast autolysates it can be concluded that the intensity of quality parameters increased with the increase in concentration of the autolysate in the solution. Sensory quality of yeast autolysates solutions was complex and depended on the presence and the changing the intensity of many flavour traits. The sensory profile of the tested yeast autolysates was clearly dependent on such notes as yeast, fermentation, "beer", bitter-astringent and roasting. It was observed that autolysates obtained after 20 hours of the autolysis process were characterised by the least intensive aroma, such as yeast, fermentation, beer, cereal and acid as compared to other autolysates. These autolysates were also characterised by the highest clarity and lowest amount of sediment and represented the lowest rate of fermentation and beer taste. The intensity of the other quality parameters was comparable, irrespective to the duration of the autolysis process. Overall quality remained at the highest level for the autolysates obtained after 20 hours of the autolysis process.

\section{Conclusions}

I. The post-fermentation brewing yeast may be a valuable material for the preparation of yeast autolysates which can be then used in the production of functional food and dietary supplements. The functional properties of obtained autolysates were affected by the use of yeast slurry rich in amino acids and the bioactive compounds derived from barley and hops used for beer production.

II. The obtained yeast autolysates were characterised by a high content of amino acids, exciding the amount present in the reference protein developed by FAO/WHO. Varied content of free amino acids and high content of low weight molecular peptides in autolysates is very advantageous and may indicate the possibility of their broader use in functional food and dietary supplements.

III. The obtained autolysates were characterised by a high antioxidant properties, which were affected, among others, by polyphenolic 
Citation: Podpora B, Świderski F, Sadowska A, Piotrowska A, Rakowska R (2015) Spent Brewer's Yeast Autolysates as a New and Valuable Component of Functional Food and Dietary Supplements. J Food Process Technol 6: 526. doi:10.4172/2157-7110.1000526

compounds derived from hops and malt present in the postfermentation yeast slurry used for autolysate production.

IV. The tested autolysates were characterised by a different sensory profile with a clearly noticeable bitter aftertaste derived from bitter substances extracted from hops. This bitter aftertaste changes favourably with the increase in duration of the autolysis process and growth of free amino acids content, particularly glutamic acid.

V. The sensory quality and functional properties of autolysates derived from post-fermentation yeasts are dependent on the degree of the yeast protein autolysis which determines their usage in a food production.

VI. Precise time control of the autolysis process allows obtaining a product with designed composition and functional properties. Such product is characterised by a desired content of free amino acids, peptides with a specific molecular weight and antioxidant properties.

\section{References}

1. Waszkiewicz-Robak B (2013) Spent Brewer's Yeast and Beta-Glucans Isolated from Them as Diet Components Modifying Blood Lipid Metabolism Disturbed by an Atherogenic Diet: Lipid Metabolizm. InTech Pub, Rijeka, Croatia.

2. Breddam K, Beenfeld T (1991) Acceleration of yeast autolysis by chemical methods for production of intracellular enzymes. Applied Biochemistry and Microbiology 35: 323-329.

3. Chae HJ, Joo H, In MJ (2001) Utilization of brewer's yeast cells for the production of food-grade yeast extract, Part 1: Effects of different enzymatic treatments on solid and protein recovery and flavor characteristics. Bioresource Technology 76: 253-258.

4. Choi SJ, Chung BH (1998) Simultaneous production of invertase and yeast extract from baker's yeast. Biotechnology and Bioengineering 13: 308-311.

5. Nagodawithana T (1992) Yeast-derived flavors and flavor enhancers and their probable mode of action. Food Technology 46: 138-144

6. Belousova NI, Gordienko SV, Eroshin VK (1995) Influence of autolysis conditions on the properties of amino-acid mixtures produced by ethanolassimilating yeast. Applied Biochemistry and Microbiology 31: 391-395.

7. Peppler HJ (1982) Yeast extracts. Economic Microbiology. Academic Press London.

8. Stone CW (1998) Yeast Products in the Feed Industry: A Practical Guide for Feed Professionals. Diamond V Mills, Cedar Rapids, lowa.

9. In MJ, Kim DC, Chae HJ (2005) Downstream process fort the production of yeast extract using brewer's yeast cells. Biotechnology and bioprocess engineering 10: 85-90.

10. Lee C, Tsang SK, Urakabe R, Rha CK (1979) Disintegration of dried yeast cells andist effect on protein extractability, sedimentation property and viscosity of the cell suspension. Biotechnology and Bioengineering 21: 1-17.

11. Sommer R (1998) Yeast Extracts: Production, Properties and Components Food Australia 50: 181-183.

12. AOAC (1995) Official methods of analysis of the Association of Official Analytical Chemists. Arlington, Virginia, USA

13. Stephens K (1986) Amino Acid Analysis by Dansylation: A Revised Method. Bal State University, Muncie, Indiana.

14. Bech-Andersen S (1991) Determination of Tryptophan with HPLC after Alkaline Hydrolysis in Autoclave using a-methyl-tryptophan as Internal Standard. Acta Agriculturae Scandinavica 41: 305-309.

15. Block RJ , Mitchell HH (1946) The Correlation of the Amino Acid Composition of Proteins with their Nutritive Value. Nutrition Abstracts and Reviews 16: 249-278.

16. Oser BL (1951) Methods for the integrating essential amino acid content in the nutritional evaluation of protein. J Am Dietetic Assoc 27: 399-404.

17. FAO/WHO (1991) Protein quality evaluation. Report of the Joint FAO/WHO
Expert Consultation. FAO Food and Nutrition Paper 51. Food and Agriculture Organization of the United Nations, Rome.

18. Pellegrini N, Serafini M, Colombi B, Del Rio D, Salvatore S, et al. (2003) Tota Antioxidant Capacity of Plant Foods, Beverages and Oils Consumed in Italy Assessed by Three Different In Vitro Assays. American Society of Nutritional Sciences 6: 2812-2819.

19. Singleton VL, Rossi JA (1965) Colorimetry of total phenolics with phosphomolybdic-phosphotungstic acid reagents. American Journal of Enology and Viticulture 16: 144-158.

20. BS EN ISO 13299:2010 Sensory analysis. Methodology. General guidance for establishing a sensory profile.

21. BSEN ISO (2010) Sensory analysis. General guidance for the design of test rooms.

22. Martini Vaughan AE, Miller MW, Martini A (1979) Amino Acid Composition of Whole Cells of Different Yeasts. J Agric Food Chem 27: 982-984.

23. Yamada EA, Sgarbieri VC (2005) Yeast (Saccharomyces cerevisiae) Protein Concentrate: Preparation, Chemical Composition, and Nutritional and Functional Properties. J Agric Food Chem 53: 3931-3936.

24. Mez-alonso SG, Rrez IH, Garciaa-romero E (2007) Simultaneous HPLC Analysis of Biogenic Amines, Amino Acids, and Ammonium lon as Aminoenone Derivatives in Wine and Beer Samples. J Agric Food Chem 55: 608-613.

25. Voss K, Galensa R (2000) Determination of L- and D-amino acids in foodstuffs by coupling of high-performance liquid chromatography with enzyme reactors. Amino Acids 18: 339-352

26. Barczak B, Nowak K (2008) Skład aminokwasowy białka biomasy jęczmienia ozimego (hordeum vulgare I.) w zależności od stadium rozwoju rośliny nawożenia azotem. Acta Sci. Pol. Agricultura 7: 3-15.

27. Gawęcki J, Hryniewiecki L (2005) Białka: Żywienie człowieka, Gawęcki J, Polskie Wydawnictwo Naukowe.

28. Stryer L (1997) Biochemia. Wydawnictwo Naukowe PWN: 17-44.

29. Rose AH, Harrison JS (1970) The Yeasts, Yeast Technology. Academic Press, London.

30. Clemente A (2000) Enzymatic protein hydrolysates in human nutrition. Trends in Food Science \& Technology 11: 254-262.

31. Maldonado J, Gil A, Narbona E, Molina JA (1998) Special formulas in infant nutrition: a review. Early Human Development Suppl 53: 23-32.

32. Netto FM, Galeazzi MA (1998) Production and characterization of enzymatic hydrolysate from soy protein isolate. Lebensm-Wiss u-Technol 31: 624-631.

33. Risch SJ, Ho CT (2000) Flavor Chemistry. Industrial and academic research Studies on potent aroma compounds generated in Maillard-type reactions using using the odor-activity-value concept. American Chemical Society, Washington DC: $133-150$.

34. Moure A, Dominguez H, Parajo JC (2006) Antioxidant properties of ultrafiltrationrecovered soy protein fractions from industrial effluents and thei hydrolysates. Process Biochemistry 41: 447-456. 